\title{
Michel al-Maqdissi. Note d'Archéologie Levantine. XXI. Travaux archéologiques à Tell Ghamqa au sud de Tartous en 1926
}

\section{Astrid Nunn}

\section{(2) OpenEdition Journals}

Édition électronique

URL : http://journals.openedition.org/abstractairanica/40376

DOI : 10.4000/abstractairanica.40376

ISSN : 1961-960X

Éditeur :

CNRS (UMR 7528 Mondes iraniens et indiens), Éditions de l'IFRI

Édition imprimée

Date de publication : 1 décembre 2013

ISSN : 0240-8910

Référence électronique

Astrid Nunn, « Michel al-Maqdissi. Note d'Archéologie Levantine. XXI. Travaux archéologiques à Tell Ghamqa au sud de Tartous en 1926 », Abstracta Iranica [En ligne], Volume 32-33 | 2013, document 100, mis en ligne le 01 juillet 2016, consulté le 28 septembre 2020. URL : http://journals.openedition.org/ abstractairanica/40376 ; DOI : https://doi.org/10.4000/abstractairanica.40376

Ce document a été généré automatiquement le 28 septembre 2020.

Tous droits réservés 


\title{
Michel al-Maqdissi. Note d'Archéologie Levantine. XXI. Travaux archéologiques à Tell Ghamqa au sud de Tartous en 1926
}

\author{
Astrid Nunn
}

\section{RÉFÉRENCE}

Michel al-Maqdissi. « Note d'Archéologie Levantine. XXI. Travaux archéologiques à Tell Ghamqa au sud de Tartous en 1926 ». Al-Rāfidān, 31, 2010, p. 85-89.

1 Outre les grandes fouilles, de nombreux sondages ont été faits lors du mandat français en Syrie. Leur documentation est dispersée et n'a pas toujours été publiée. L'A. présente ici un carnet d'inventaire, rédigé par M. Dunand en 1926 et conservé dans le fonds d'archives de Maurice Dunand à l'Université de Genève. Il s'agit du Tell Ghamqa, sondé en 1926 par M. Dunand, alors qu'il travaillait à Amrit, et fouillé par une équipe syrienne en 2005. M. Dunand en inventoria quelques objets. Le niveau V de Ghamqa correspond au Fer III.

\section{AUTEURS}

ASTRID NUNN

Université de Munich 